Nat. Hazards Earth Syst. Sci., 17, 1559-1571, 2017

https://doi.org/10.5194/nhess-17-1559-2017

(C) Author(s) 2017. This work is distributed under

the Creative Commons Attribution 3.0 License.

\title{
Assessing storm surge hazard and impact of sea level rise in the Lesser Antilles case study of Martinique
}

\author{
Yann Krien $^{1}$, Bernard Dudon ${ }^{1}$, Jean Roger ${ }^{1,2}$, Gael Arnaud ${ }^{1}$, and Narcisse Zahibo ${ }^{1}$ \\ ${ }^{1}$ LARGE, Laboratoire de Recherche en Géosciences, Université des Antilles, Guadeloupe, France \\ ${ }^{2}$ G-Mer Etudes Marines, Guadeloupe, France \\ Correspondence to: Yann Krien (ykrien@gmail.com)
}

Received: 17 April 2017 - Discussion started: 25 April 2017

Revised: 20 July 2017 - Accepted: 3 August 2017 - Published: 18 September 2017

\begin{abstract}
In the Lesser Antilles, coastal inundations from hurricane-induced storm surges pose a great threat to lives, properties and ecosystems. Assessing current and future storm surge hazards with sufficient spatial resolution is of primary interest to help coastal planners and decision makers develop mitigation and adaptation measures. Here, we use wave-current numerical models and statistical methods to investigate worst case scenarios and 100-year surge levels for the case study of Martinique under present climate or considering a potential sea level rise. Results confirm that the wave setup plays a major role in the Lesser Antilles, where the narrow island shelf impedes the piling-up of large amounts of wind-driven water on the shoreline during extreme events. The radiation stress gradients thus contribute significantly to the total surge - up to $100 \%$ in some cases. The nonlinear interactions of sea level rise (SLR) with bathymetry and topography are generally found to be relatively small in Martinique but can reach several tens of centimeters in low-lying areas where the inundation extent is strongly enhanced compared to present conditions. These findings further emphasize the importance of waves for developing operational storm surge warning systems in the Lesser Antilles and encourage caution when using static methods to assess the impact of sea level rise on storm surge hazard.
\end{abstract}

\section{Introduction}

Coastal urbanization and industrialization in storm-surgeprone areas pose great challenges for adaptation and mitigation. Human and economic losses due to water extremes have considerably increased over the last decades (WMO, 2014) and are expected to continue to do so in many areas worldwide because of coastal population growth (Neumann et al., 2015) and climate change impacts (sea level rise, SLR; deterioration of protected marine ecosystems; potential increase in the frequency of extreme events; etc.). It is therefore necessary to better assess current and future storm surge hazards to help decision makers regulate land use in coastal areas and develop mitigation strategies.

The Lesser Antilles are the first islands on the path of hurricanes that originate off the west coasts of Africa and strengthen during their travel across the warm waters of the tropical Atlantic Ocean. They are therefore regularly exposed to extremely severe winds and waves causing great human and economic losses. In the center of the Lesser Antilles Archipelago lies Martinique, a French insular overseas region which shares similar characteristics with neighboring islands, such as a relatively narrow island shelf, fringing coral reefs, mangrove forests, numerous bays and contrasted slope morphologies.

Although Martinique has been relatively spared over the last decades compared to other islands such as Dominica or Guadeloupe, it still largely suffered from massive destruction in coastal areas due to hurricanes passing nearby (Durand et al., 1997; Pagney and Leone, 1999; Saffache, 2000; Léone, 2007; Duvat, 2015). A recent example is hurricane Dean (category 2), which struck the island in 2007, causing severe damages, especially along the exposed east coast (Barras et al., 2008).

About 15 years ago, the French national meteorological service delivered a preliminary map of 100-year surge heights in Martinique (Météo France, 2002). These early results were of great interest and have been used extensively 
by coastal planners since then (Grau and Roudil, 2013). At the time, however, wave-current interactions were not taken into account, although waves were already known to have a strong impact on surges in coastal areas (e.g., Wolf et al., 2011; Brown et al., 2011). Water levels were thus expected to be underestimated, especially in areas exposed to waves.

Over the past few years, significant progress has been made in developing wave-current coupled models (e.g., Dietrich et al., 2012; Roland et al., 2012; Kumar et al., 2012; Qi et al., 2009; Bennis et al., 2011; Dutour Sikiric et al., 2013), but no attempt has been made so far to improve storm surge hazard assessment in Martinique. The preliminary results are thus still largely used as a reference by decision makers, and recent works investigate the impacts of historical events (e.g., Barras et al., 2008) or the ability of numerical models to reproduce extreme water levels and inland flooding (Nicolae Lerma et al., 2014).

The potential impacts of climate change have also received little attention. Although the effect of a warmer climate remains relatively uncertain in terms of hurricane activity in the North Atlantic (e.g., Knutson et al., 2010), a significant increase in sea level is expected in the Lesser Antilles in the coming decades (Palanisamy et al., 2012). Moreover, coastal ecosystems such as mangroves, coral reefs or seagrass beds may not be able to adapt to climate change (e.g., Waycott et al., 2009; Wong et al., 2014), which could have large impacts on coastal flooding (e.g., Alongi, 2008; Wong et al., 2014).

Here we investigate storm surge hazard in Martinique in greater detail and derive more accurate 100-year surge heights and maximum surge levels, using state-of-the-art numerical models and the statistical-deterministic approach of Emanuel et al. (2006). We also conduct preliminary tests to investigate the impact of sea level rise (SLR) in the following decades. The present paper is organized as follows: after a short presentation of the study area (Sect. 2), we describe the methodology (Sect. 3) and the numerical model (Sect. 4). The results are shown in Sect. 5. The limitations of this study and material for further research are given in Sect. 6. The main conclusions can be found in Sect. 7.

\section{Study area}

Located in the center of the Lesser Antilles (Fig. 1a), Martinique is a French mountainous island of about 390000 inhabitants, with a remarkable variety of coastal environments (mangroves, cliffs, sandy coves, coral reefs, highly urbanized areas, etc.) and contrasted sea bottom morphologies. The Atlantic coast is characterized by barrier and fringing coral reefs, as well as a gently dipping dissipating shelf promoting relatively large storm surges, whereas most of the Caribbean beaches are reflective, with waves propagating onshore without significant attenuation, except in the Bay of Fort-de-France (Fig. 1).
A large part of the population has been living close to the shoreline for centuries, for historical or economic reasons, such as military defense or fishing activities (EPRI, 2012). This trend is being accentuated with the development of tourism infrastructures since the 1960s (Desarthe, 2014). The number of tourists has tripled since 1995, even though the sector has undergone a deterioration recently (Dehoorne et al., 2014). Coastal zones are now highly coveted and densely populated areas (Garnier et al., 2015), which are prone to natural hazards such as erosion, storm surges or tsunamis (e.g., Poisson and Pedreros, 2007). The Bay of Fort-de-France has been identified as a particularly vulnerable area by the French government services, in the framework of the EU Floods Directive (PGRI, 2014). Indeed, this relatively low-lying zone concentrates a great part of the industry, services and transport infrastructures (highway, airport, etc.). In addition, the mangrove forest of Lamentin (Fig. 1b) is one of the largest remaining mangroves of the Caribbean and an important ecological area supporting a great variety of animal species.

Martinique is regularly affected by severe storms: about one hurricane every 10 years on average, according to the data provided by NOAA's Office for Coastal Management (Fig. 2). Fortunately, it has been relatively spared over the past decades compared to neighboring islands such as Dominica or Guadeloupe, with only one hurricane making landfall on the island since 1900 (Fig. 2). The main historical hurricane event is probably the hurricane that hit Martinique in 1780, resulting in about 9000 fatalities (Saffache et al., 2002). More recently, Dean (a category 5 hurricane that passed Martinique as a category 2 storm in 2007) caused very extensive damage to the urban areas close to the coast as well as severe coastline erosion (Barras et al., 2008). Significant destructions also arose in recent years because of energetic swells generated by hurricanes traveling eastward in the Caribbean Sea (e.g., Omar in 2008 or Lenny, 1999). The reflective Caribbean coast is particularly exposed to this type of event.

Marine ecosystems such as coral reefs or mangroves are known to provide substantial protection against waves and surges during hurricanes (e.g., Ferrario et al., 2014). In Martinique, however, mangrove forests have at least partially deteriorated due to earthworks, water and soil pollution, or hurricanes (e.g., Imbert and Migeot, 2009). The situation is even worse for coral reefs, for which a dramatic decline due to eutrophication, anthropogenic disturbances or extreme storms has been observed over the past 40 years (Bouchon and Laborel, 1986; Legrand et al., 2008; Rousseau et al., 2010; IFRECOR, 2016). The deterioration of these marine ecosystems because of climate change is thus a cause of major concern for the coming decades.

A warmer climate is also expected to induce a significant increase in sea level in Martinique. Since the regional trends are very similar to the global mean rate (Palanisamy et al., 2012), the mean sea level might rise by several dozens of cen- 

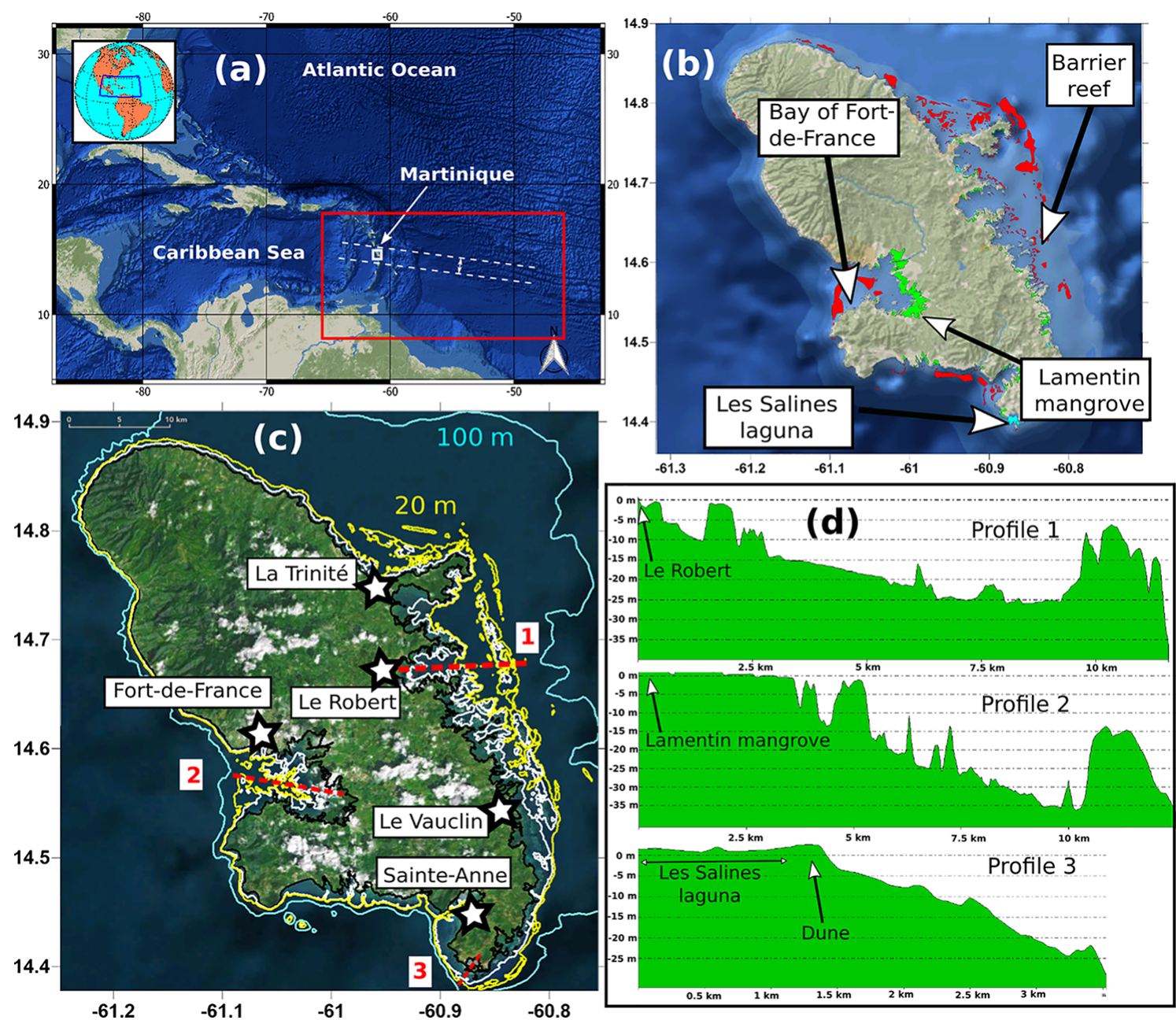

Figure 1. (a) Area of interest. The computational domain is given in red. Dashed white lines represent the southernmost and northernmost tracks considered for the "worst case scenarios" (Sect. 5.1). (b) Focus on Martinique and the location of coral reef communities (red), mangroves areas (green) and lagoons (cyan). Source of data: agence des aires marines protégées. (c) Isobaths at $10 \mathrm{~m}$ (white), $20 \mathrm{~m}$ (yellow), and $100 \mathrm{~m}$ (cyan), as well as location of the bathymetric profiles displayed in (d).

timeters or more in the coming decades. All these findings strongly encourage coastal planners and scientists to better assess current and future storm surge hazard along the coastline of Martinique in order to develop mitigation strategies.

\section{Methodology}

To achieve this goal, we conducted numerical investigations using a wave-current coupled model (Sect. 4). As a first step, we computed the maximum surge obtained for a few synthetic severe (category 4-5) hurricanes. The aim is to better understand the mechanisms responsible for generating storm surges in Martinique and to crudely estimate the maximum surges that could be reached along the coastline for extreme events. To do this, we generated 13 synthetic hurricanes striking Martinique, with maximum velocity $V_{\max }=140 \mathrm{kn}$ (knot), radius of maximum winds $R_{\max }=20 \mathrm{~km}$, track angle of $10^{\circ}$ with respect to an east-west profile, and translation speed $V_{\mathrm{t}}=12 \mathrm{kn}$. These values represent typical characteristics of major hurricanes in Martinique (Sansorgne, 2013). A few sensitivity tests were performed to ensure that track angle and translation speed are of second order compared to hurricane intensity and distance to the area of interest (Sansorgne, 2013).

The tracks parallel each other and are spaced $10 \mathrm{~km}$ apart to take into account almost all the possible landfall locations. The southernmost and northernmost tracks are displayed in Fig. 1.

In a second phase, we derived new 100-year surge levels. This step is relatively complex for regions prone to cyclones because of the dearth of events in historical records. Traditional extreme value analysis methods are generally found to not be applicable in these areas, so more advanced statistical approaches are needed to infer water level return peri- 


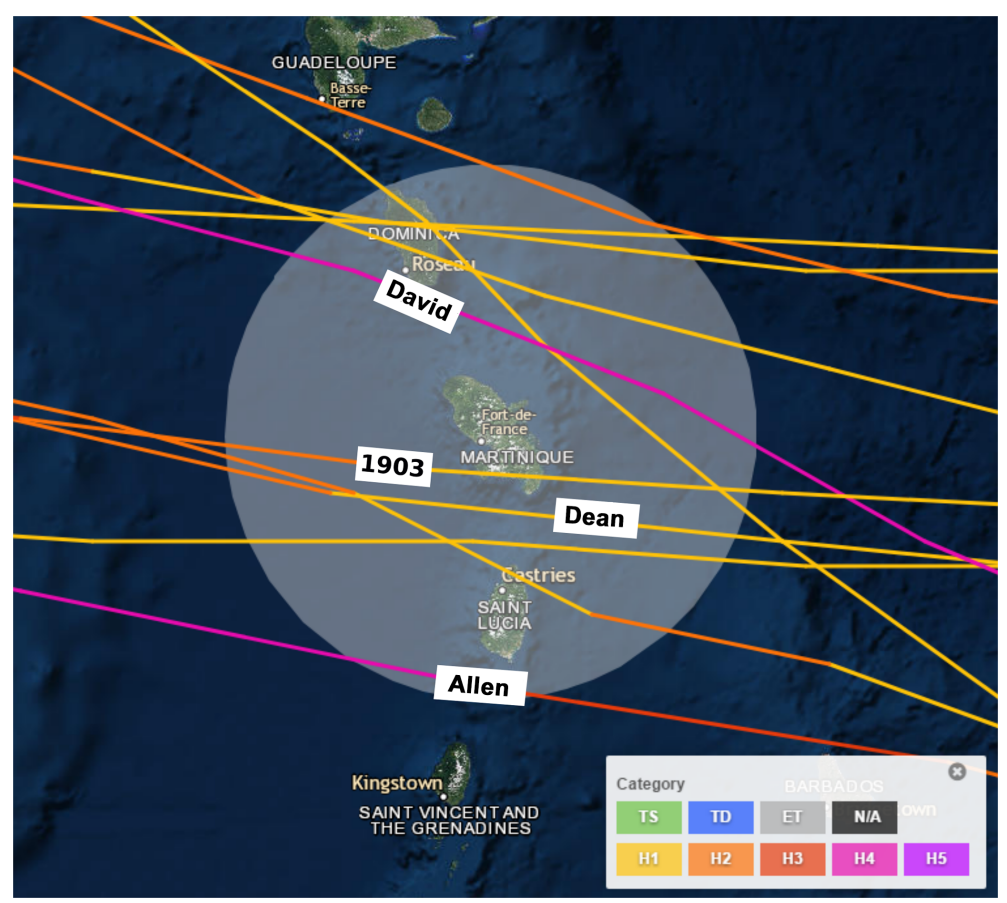

Figure 2. Tracks and intensities of historical hurricanes passing within 65 nautical miles from Martinique, since 1900. (source: NOAA's Office for Coastal Management, https://coast.noaa.gov/hurricanes/).

ods. These methods involve the generation of a large number of synthetic cyclones that are in statistical agreement with observations. Several approaches have been proposed so far, such as JPM-OS (Joint Probability Methods with Optimal Sampling, e.g., Resio, 2007; Toro et al., 2010) or the statistical-deterministic model of Emanuel et al. (2006). They have been used successfully for storm surge assessment at local (Lin et al., 2010, 2012), regional (Harper et al., 2009; Niedoroda et al., 2010) or even continental (Haigh et al., 2014) scales. In the present paper, we use the statistical-deterministic approach of Emanuel et al. (2006), which provided good results for Guadeloupe in a previous study (Krien et al., 2015). This method consists of four main steps (Emanuel et al., 2006):

1. The genesis locations of the new synthetic storms are obtained by a random draw from a space-time probability density function derived from historical genesis point data.

2. For each storm considered, synthetic time series of the zonal and meridional wind components at 250 and $850 \mathrm{hPa}$ are generated. They are designed to conform to the climatologies derived from NCEP-NCAR reanalysis between 1980 and 2011. In particular, the observed monthly means and variances are respected, as well as most covariances. The wind time series are regenerated if the initial vertical shear is too strong to be conducive to a storm.
3. The storm track is then derived from a weighted mean of the 250 and $850 \mathrm{hPa}$ flow plus a correction for beta drift (Emanuel et al., 2006). The weight factor and betadrift terms are chosen to optimize comparisons between the synthesized and observed displacement statistics.

4. The intensity along the synthetic track is obtained using a numerical model developed by Emanuel et al. (2004). The wind shear is given by the synthetic time series of winds determined previously. The monthly mean climatological upper-ocean thermal structure is taken from Levitus (1982).

The full database developed for this study contains 3200 low-pressure events (tropical depressions, tropical storms and hurricanes) passing within $100 \mathrm{~km}$ from Fort-de-France (Fig. 3).

It represents about 8000 years of hurricane activity under the present climate conditions in the immediate vicinity of Martinique. In practice, however, we computed only the surges for the strongest events, as tropical storms and depressions are not found to be able to generate water levels with a 100-year return period. In all, 700 events were simulated on a 240-core computational cluster.

In both cases, we also investigated the effect of a $1 \mathrm{~m}$ sea level rise. Considering that the sea level trend in the Lesser Antilles is very similar to the global mean rate (Palanisamy et al., 2012), this value of $1 \mathrm{~m}$ roughly corresponds to the global projections of IPCC by 2100 in the case of a high emission scenario (IPCC, 2013). Considering that coral reefs 


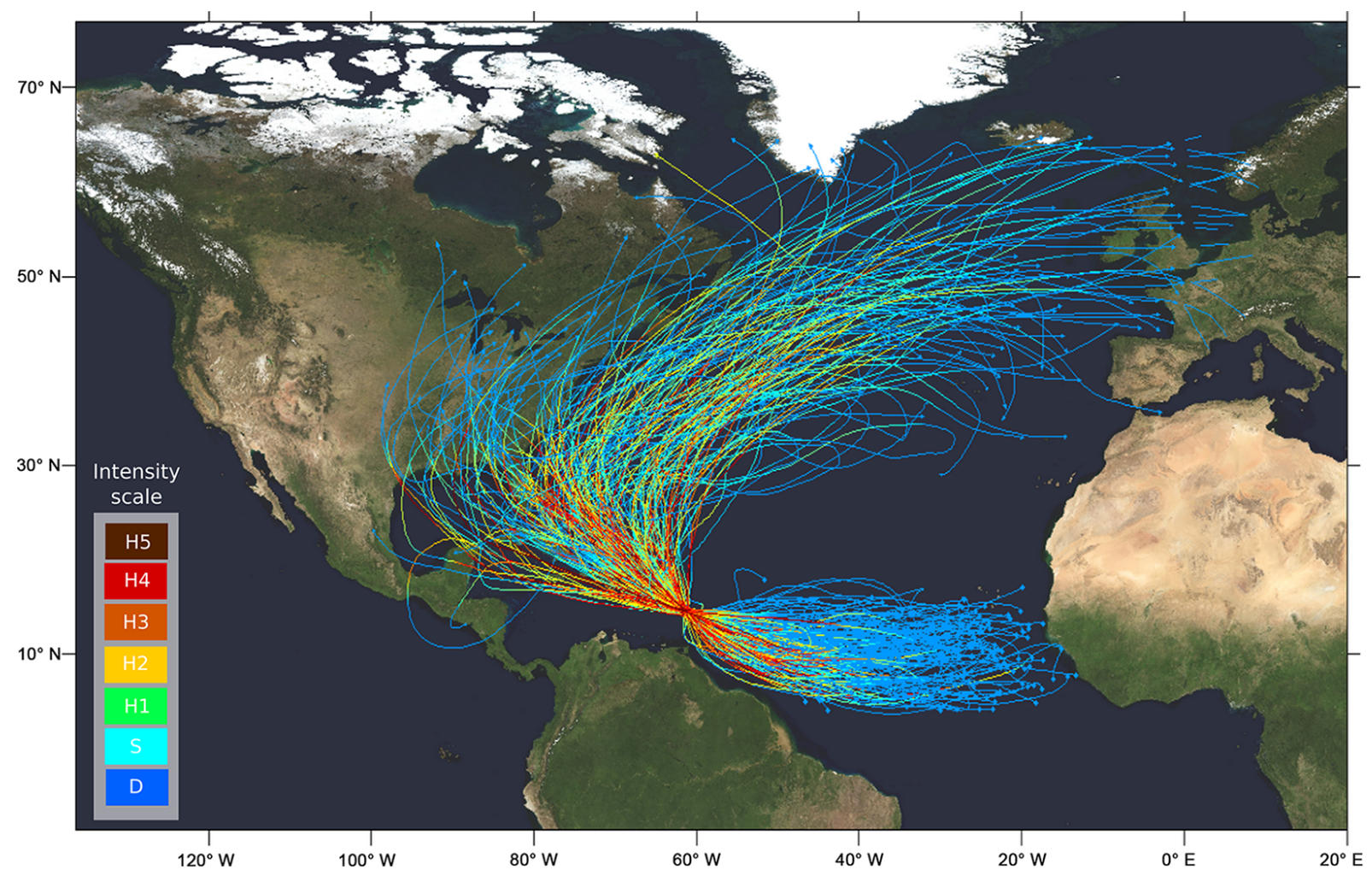

Figure 3. Examples of synthetic hurricanes generated for this study, using the statistical-numerical approach of Emanuel et al. (2006).

and mangroves have already deteriorated, we assume here that they will not been further damaged but that they cannot keep pace with SLR. In practice, this amounts to a rise in the water level of $1 \mathrm{~m}$, without changing the shape of bathymetry or topography.

\section{Numerical model}

\subsection{Model description}

In this study we employed the wave-current coupled model ADCIRC + SWAN (Dietrich et al., 2012). ADCIRC (ADvanced CIRCulation Model, Luettich et al., 1992; Westerink et al., 1994) is a finite-element hydrodynamic model that solves the depth-averaged barotropic form of the shallow water equations on unstructured grids. Water levels are obtained from the solution of the generalized wave-continuity equation, whereas currents are derived from the vertically integrated momentum equation. A wetting-drying algorithm is also included to allow inland overflowing.

After several sensitivity tests to achieve stability of the model and results while keeping reasonable computing time, a time step of $1 \mathrm{~s}$ was chosen.

ADCIRC (v50) is coupled to the wave model SWAN (Simulating WAves Nearshore, Booij et al., 1999), which predicts the evolution in time and space of the wave action density spectrum and has been converted recently to also run on unstructured meshes (Zijlema et al., 2010). Computations are performed here using 36 directions and 36 frequency bins. Source terms include wind input (Cavaleri and Malanotte-Rizzoli, 1981; Komen et al., 1984), quadruplet interactions (Hasselmann et al., 1985), whitecapping (Komen et al., 1984), triads (Eldeberky, 1996), bottom friction (Madsen et al., 1988) and wave breaking (Battjes and Janssen, 1978).

SWAN is forced by the wind velocities, water levels and currents given by ADCIRC and passes back the radiation stress gradients every $10 \mathrm{~min}$ (Dietrich et al., 2012). Bottom friction is computed in ADCIRC using a Manning formulation. The coefficients are converted to roughness length by SWAN. The Manning coefficient here depends on land cover (European Union, 2006). The values can be found in Krien et al. (2015) and are displayed in Fig. 4a. Note that we did not consider a strong dissipation of energy at the bottom for coral reefs, as they are known to be very eroded in Martinique (IFRECOR, 2016).

The model is forced by wind and pressure fields, calculated using the gradient wind profiles of Emanuel and Rotunno (2011) and Holland (1980) respectively (see Krien et al., 2015, for more details).

Topography and bathymetry in shallow waters (up to about $40 \mathrm{~m}$ depth) are specified using high-resolution lidar data (Litto3D Program). On the shelf, ship-based sound- 
ing data acquired by the French Naval Hydrographic and Oceanographic Department (SHOM) are also included. GEBCO (General Bathymetric Chart of the Oceans) data with 30 arcsec resolution are used for deep water areas.

The effect of tides are neglected here as their amplitude is very low in Martinique (less than $35 \mathrm{~cm}$ ).

The computational domain is displayed in Fig. 1. The resolution spans from $10 \mathrm{~km}$ in the deep ocean to about $50 \mathrm{~m}$ on the coastline and coral reefs (Fig. 4b).

\subsection{Model performance}

This model has been used and validated for various storm events around the world (e.g., Dietrich et al.,, 2011a, b, 2012; Hope et al., 2013; Kennedy et al., 2011; Murty et al., 2016). It was also found to give good results for several islands in the Lesser Antilles, such as Guadeloupe and Martinique (Krien et al., 2015; Nicolae Lerma et al., 2014).

In the course of the present study, we conducted a few more validation tests, such as for hurricane Dean (2007). Results are consistent with observations, but those are not sufficiently accurate and compelling to really add relevant information regarding the ability of the model to reproduce storm surges. As an example, the tide gauge located at Le Robert recorded a surge peak (of about $20 \mathrm{~cm}$ according to our estimates) on 17 August 2007, but this value is probably significantly underestimated since only hourly data are available. Our model predicts higher values (about $75 \mathrm{~cm}$ ), which are more consistent with observations made by witnesses, who reported that the garden south of the city center $\left(14.6753^{\circ} \mathrm{N}\right.$, $60.9387^{\circ} \mathrm{W}$ ) was partially under water. Similarly, only small surges (less than $20 \mathrm{~cm}$ ) were recorded in Fort-de-France (Barras et al., 2008) for hurricane Dean. This is again consistent with the model prediction $(15 \mathrm{~cm})$, but not really satisfying in terms of validation for extreme events. Similarly, in the most impacted areas, such as Le Vauclin, only indirect information about the maximum water level is available (e.g., Barras et al., 2008). Although they are again in agreement with the predictions of the numerical model (about $1.5 \mathrm{~m}$ above mean sea level), systematic measurements of water levels should be performed in the future to be able to better assess the ability of the model to reproduce storm surges. Note that preliminary validation tests were also performed for waves and give satisfying results (Krien, 2013).

\section{Results}

\subsection{Test cases for a few synthetic hurricanes and maximum surge levels}

The results obtained for a few "worst case" (category 4-5) events are displayed in Fig. 5 and Table 1. The water levels on the Caribbean coast are found to be largest for hurricanes making landfall in the northern part of Martinique. This was expected since in this case the winds on the west coast are essentially onshore when hurricanes pass over the island.

Water levels can exceed $4 \mathrm{~m}$ above mean sea level in the upper part of the Bay of Fort-de-France for extreme events (Fig. 5a). In that case, most of the surge is driven by the wind. The wave setup only contributes a few tens of centimeters to the total water levels (Fig. 5b). This component plays a crucial role on the Atlantic coast, where it can reach $1 \mathrm{~m}$. In some locations, such as Le Vauclin, the wave setup accounts for almost all the total surge.

On the eastern coast, the surge is maximum for hurricanes passing south of Martinique. For category 4-5 hurricanes (such as the ones modeled here), it can exceed $3 \mathrm{~m}$ locally (Fig. 5c). The wave setup is still significant (up to about $1 \mathrm{~m}$ ) in the shallow waters between the coastline and the coral reefs on the Atlantic coast (Fig. 5d). This contribution can amount to about $50 \%$ of the total surge along the southeastern coasts of Martinique in the test case considered here.

Figure $5 \mathrm{e}$ and $\mathrm{f}$ show the results obtained when considering a sea level rise of $1 \mathrm{~m}$. The wave setup is found to be only slightly modified, with a reduction of a few centimeters in general compared to the case without sea level rise Fig. 5d. The wind-driven surge is significantly attenuated near the shore (by a few tens of centimeters), because wind stresses are less efficient in driving water masses towards the coast when the water depth is higher (comparison between Fig. 5c and Fig. 5e).

The maximum water levels computed using the 13 synthetic category 4-5 hurricanes are presented in Fig. 6a. As mentioned above, the maximum surges are obtained for the bay of Fort-de-France, where water levels can exceed $4 \mathrm{~m}$ above mean sea level. The head of the bay, where high environmental and transportation stakes are located (e.g., airport, national roads, mangrove forest), is particularly exposed.

The shallow waters of the eastern coast also promote significant surges, which can reach about $3 \mathrm{~m}$. On the other hand, the steep slopes characterizing most of the western part of Martinique impedes strong wind surges and are generally not directly exposed to waves, so maximum water levels are considerably reduced. Note, however, that the grid resolution (about $50 \mathrm{~m}$ ) is probably not sufficient to fully capture the wave setup in these areas, so the maximum surge (about $1 \mathrm{~m}$ ) might be somewhat underestimated.

A sea level rise of $1 \mathrm{~m}$ would have potentially major impacts, for example, in the urban area of Fort-de-France (Fig. 6b) where many buildings could be flooded in the case of a severe storm.

\subsection{Statistical storm surge analysis}

The 100-year surge levels obtained using the database described in Sect. 3 are plotted in Fig. 7a. Since extreme hurricanes striking Martinique are rather scarce, these levels are found to be significantly smaller than the maximum surges estimated above, by a factor of 2 or more. However, they 

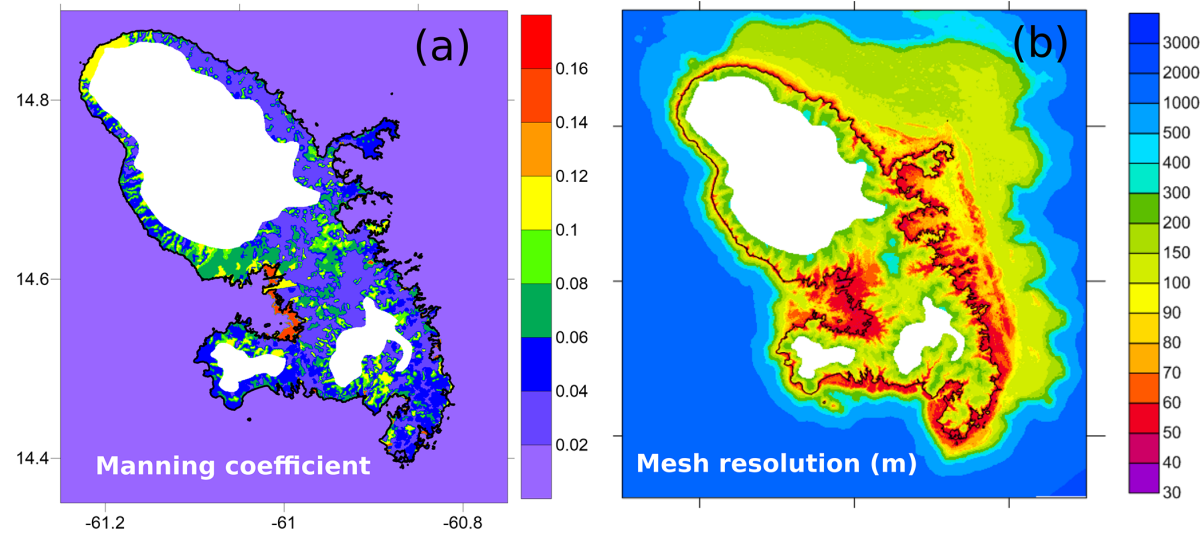

Figure 4. (a) Spatial variation of the Manning coefficient $n$, based on land cover data (European Union, 2006). (b) Spatial variation of the mesh resolution in the vicinity of Martinique.

Table 1. Maximum storm surges (in meters) predicted by the model for the 13 worst case scenarios at four different locations: Fort-de-France tide gauge, airport, Le Robert tide gauge, and Le Vauclin. The distance of the hurricane track from Fort-de-France is also given. (S) or (N) refers to a storm passing south or north of Fort-de-France respectively. The maximum values obtained for each location are shown in bold.

\begin{tabular}{|c|c|c|c|c|c|c|}
\hline $\begin{array}{l}\text { Test } \\
\text { case }\end{array}$ & $\begin{array}{l}\text { Distance from } \\
\text { Fort-de-France } \\
(\mathrm{km})\end{array}$ & $\begin{array}{l}\text { Sea level } \\
\text { rise } \\
(1 \mathrm{~m})\end{array}$ & $\begin{array}{l}\text { Surge Fort-de-France } \\
\left(61.063^{\circ} \mathrm{W},\right. \\
\left.14.6^{\circ} \mathrm{N}\right)\end{array}$ & $\begin{array}{l}\text { Surge airport } \\
\left(61.016^{\circ} \mathrm{W}\right. \\
\left.14.593^{\circ} \mathrm{N}\right)\end{array}$ & $\begin{array}{l}\text { Surge Le Robert } \\
\left(60.937^{\circ} \mathrm{W}\right. \\
\left.14.678^{\circ} \mathrm{N}\right)\end{array}$ & $\begin{array}{l}\text { Surge Le Vauclin } \\
\left(60.837^{\circ} \mathrm{W},\right. \\
\left.14.548^{\circ} \mathrm{N}\right)\end{array}$ \\
\hline \multirow[t]{2}{*}{1} & \multirow[t]{2}{*}{$59.7(\mathrm{~S})$} & no & 0.15 & 0.15 & 1.06 & 1.41 \\
\hline & & yes & 0.14 & 0.13 & 0.96 & 1.36 \\
\hline \multirow[t]{2}{*}{2} & \multirow[t]{2}{*}{$48.7(\mathrm{~S})$} & no & 0.18 & 0.16 & 1.36 & 1.76 \\
\hline & & yes & 0.16 & 0.15 & 1.24 & 1.68 \\
\hline \multirow[t]{2}{*}{3} & \multirow[t]{2}{*}{$37.8(\mathrm{~S})$} & no & 0.24 & 0.18 & 1.74 & 2.08 \\
\hline & & yes & 0.21 & 0.17 & 1.61 & 2.04 \\
\hline \multirow[t]{2}{*}{4} & \multirow[t]{2}{*}{$26.9(\mathrm{~S})$} & no & 0.39 & 0.23 & 2.18 & 2.56 \\
\hline & & yes & 0.36 & 0.21 & 2.04 & 2.44 \\
\hline \multirow[t]{2}{*}{5} & \multirow[t]{2}{*}{$16.0(\mathrm{~S})$} & no & 0.70 & 0.29 & 2.71 & 2.84 \\
\hline & & yes & 0.69 & 0.29 & 2.55 & 2.71 \\
\hline \multirow[t]{2}{*}{6} & \multirow[t]{2}{*}{$5.1(\mathrm{~S})$} & no & 1.09 & 0.85 & 3.04 & 2.54 \\
\hline & & yes & 1.09 & 0.88 & 2.90 & 2.41 \\
\hline \multirow[t]{2}{*}{7} & \multirow[t]{2}{*}{$5.8(\mathrm{~N})$} & no & 1.24 & 1.73 & 2.60 & 1.80 \\
\hline & & yes & 1.26 & 1.67 & 2.49 & 1.68 \\
\hline \multirow[t]{2}{*}{8} & \multirow[t]{2}{*}{$16.7(\mathrm{~N})$} & no & 1.11 & 2.18 & 1.40 & 1.25 \\
\hline & & yes & 1.09 & 1.99 & 1.43 & 1.18 \\
\hline \multirow[t]{2}{*}{9} & \multirow[t]{2}{*}{$27.7(\mathrm{~N})$} & no & 0.74 & 1.71 & 0.76 & 0.99 \\
\hline & & yes & 0.75 & 1.59 & 0.77 & 0.95 \\
\hline \multirow[t]{2}{*}{10} & \multirow[t]{2}{*}{$38.6(\mathrm{~N})$} & no & 0.49 & 1.29 & 0.58 & 0.82 \\
\hline & & yes & 0.50 & 1.17 & 0.60 & 0.77 \\
\hline \multirow[t]{2}{*}{11} & \multirow[t]{2}{*}{$49.5(\mathrm{~N})$} & no & 0.32 & 0.90 & 0.51 & 0.71 \\
\hline & & yes & 0.32 & 0.79 & 0.51 & 0.69 \\
\hline \multirow[t]{2}{*}{12} & \multirow[t]{2}{*}{$60.4(\mathrm{~N})$} & no & 0.22 & 0.64 & 0.45 & 0.63 \\
\hline & & yes & 0.21 & 0.54 & 0.45 & 0.62 \\
\hline \multirow[t]{2}{*}{13} & \multirow[t]{2}{*}{$71.3(\mathrm{~N})$} & no & 0.15 & 0.47 & 0.42 & 0.58 \\
\hline & & yes & 0.14 & 0.38 & 0.41 & 0.56 \\
\hline
\end{tabular}

still reach $1.5 \mathrm{~m}$ on the Atlantic coast or in the Fort-deFrance bay. These 100-year surge heights are thus significantly higher than those computed in early studies (Météo France, 2002), with discrepancies that can reach $1 \mathrm{~m}$ - for example, in the southeast. Such differences are certainly largely due to the wave-induced setup, which has been found to contribute significantly to the water levels (Sect. 5.1) and was not accounted for in the early 2000 s.

The impact of a $1 \mathrm{~m}$ sea level rise on 100-year surge levels is investigated in Fig. 7b. The nonlinear interactions between 

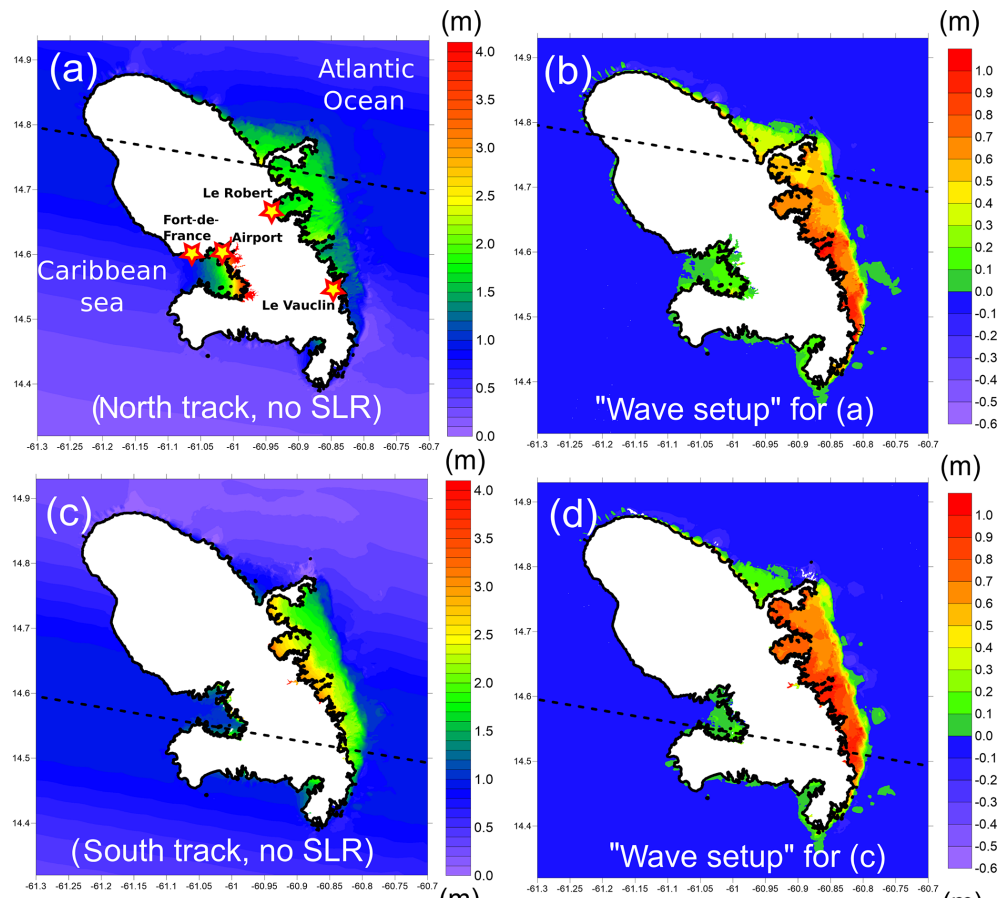

$(\mathrm{m})$

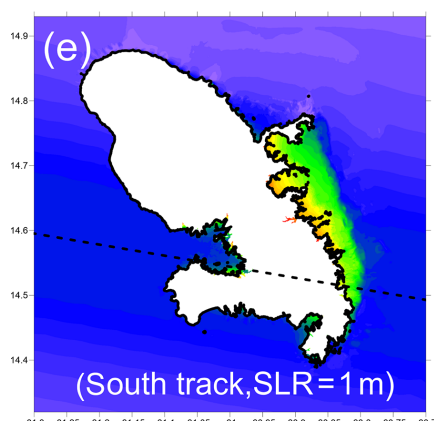

$(\mathrm{m})$
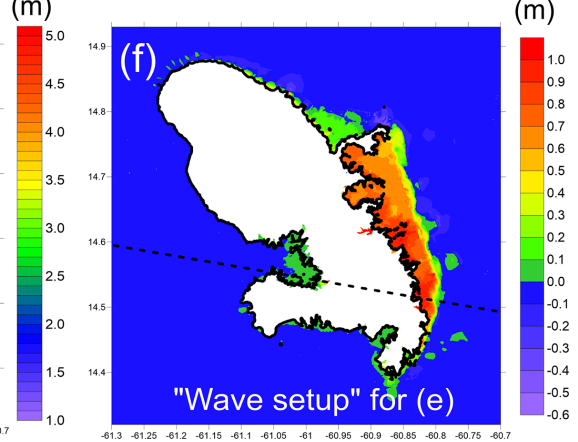

Figure 5. Maximum water levels (left) and wave setup (right) for three worst case (category 4-5) hurricanes: northern track and no sea level rise (a, b), southern track and no sea level rise (c, d), and southern track with $1 \mathrm{~m}$ sea level rise (e, f). The dashed black lines represent the track of the cyclone for each scenario. "Wave setup" refers here to the difference between the maximum water levels with and without waves. Note that the wave setup "peaks" offshore the northwest coast are probably due to small numerical instabilities in SWAN in a region with strong lateral bathymetric variations. Fortunately these errors are found to be very small $(1 \mathrm{~cm}$ maximum) and bear no consequences on the results presented in this paper.
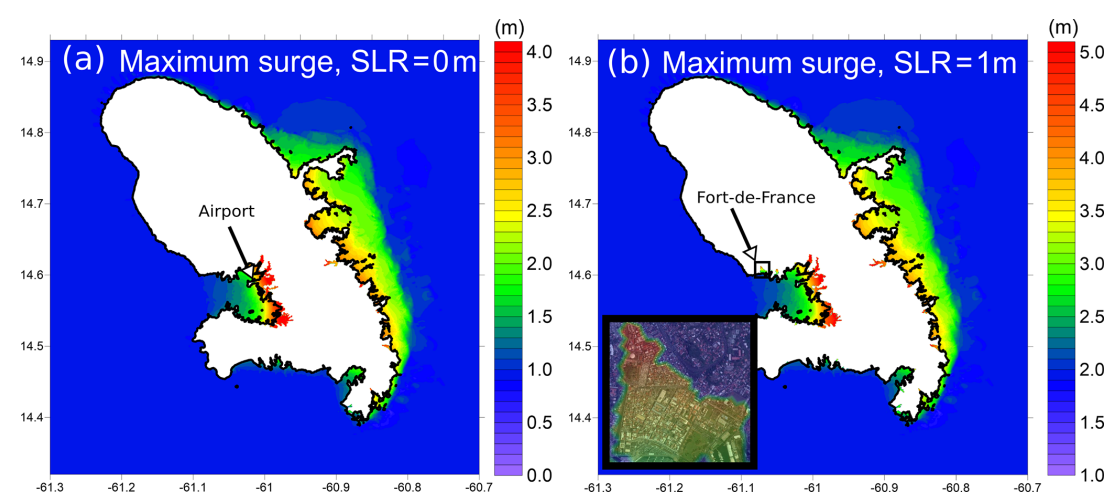

Figure 6. Maximum surges obtained by considering worst case (category 4-5) hurricanes hitting Martinique, without (a) and with (b) sea level rise. 


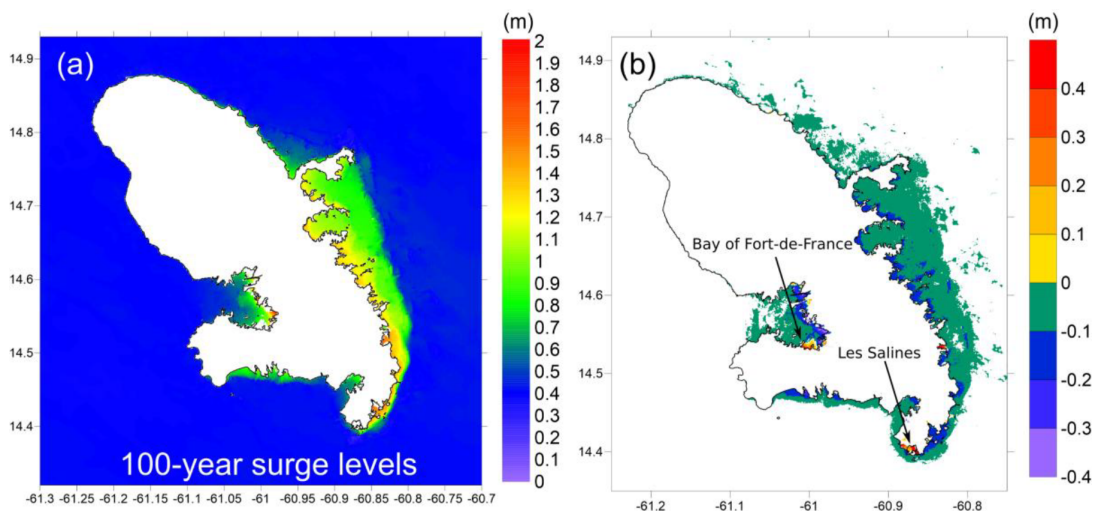

Figure 7. 100-year surge levels for present climate and no SLR (a), as well as difference between 100-year surge levels for present climate when considering a $1 \mathrm{~m}$ sea level rise (b).

surge and topography-bathymetry result in a decrease in water levels by several centimeters in most coastal areas, especially between the eastern shoreline and coral reefs, where the wave setup is reduced, and in shallow waters where the wind is less efficient in generating surges because of larger water depths. Conversely, the 100-year surges are increased inland by a few tens of centimeters in low-lying regions where the inundation extent is strongly enhanced by the sea level rise. This is the case, for example, in the bay of Fortde-France or in the Les Salines laguna, where a $1 \mathrm{~m}$ sea level rise will allow storm surges to inundate the low-lying areas beyond the sand dune (Fig. 1d).

\section{Discussion}

These results constitute a significant step forward in assessing storm surge hazard and impacts of SLR in Martinique. However, this study still leaves room for improvement. In particular, more work will be needed in the future to further investigate the impacts of climate change, including the following:

- Changes in hurricane activity. Although the effect of a warmer climate remains uncertain, a number of studies seem to reach the conclusion that the frequency of hurricanes will decrease but that these events will be on average more intense (e.g., Knutson et al., 2010). This might lead to changes in water levels for a given return period, even if preliminary works suggest that the impact could be very moderate compared to the effect of SLR (e.g., Condon and Sheng, 2012).

- Evolution of coastal ecosystems. Coral bleaching and mortality are expected to increase over the next decades due to ocean warming and acidification (e.g., HoeghGuldberg et al., 2007; Baker et al., 2008; Wong et al., 2014). Although it is not clear whether coral reefs will be able to keep up with the sea level rise in Mar- tinique, their dramatic decline due to eutrophication, anthropogenic disturbances or hurricanes over the past 40 years (Bouchon and Laborel, 1986; Legrand et al., 2008; Rousseau et al., 2010; IFRECOR, 2016) gives little reason for optimism. This could have major consequences in terms of wave impacts at coastlines, and possibly also for surges, although the results presented here suggest that this effect might be moderate. Similarly, mangrove forests have at least partially deteriorated due to earthworks, water and soil pollution, or hurricanes (e.g., Imbert and Migeot, 2009) and may have difficulty adapting to climate change in some specific areas (Gilman et al., 2008; IFRECOR, 2016). Seagrass beds already degraded by anthropic pressure or patches of Sargassum (Thabard and Pouget-Cuvelier, 2014) might experience the same fate (Waycott et al., 2009). As a consequence, shorelines might be much more vulnerable to erosion and storm surges in the following decades (e.g., Alongi, 2008; Wong et al., 2014).

- Evolution of the shoreline due to sediment transport, human activities or vertical motions. In Martinique, a few low sandy coastlines are subject to erosion and might be more exposed to relative sea level rise in the coming decades (Lemoigne et al., 2013). This is the case for several coves, especially in the south (e.g., Sainte-Anne, see Fig. 1). However, most low-lying coastal areas are rather in accretion because of natural and/or anthropic factors. This has been observed, in particular, for the bay of Fort-de-France, where a coastline extension of about $100 \mathrm{~m}$ was reported between 1951 and 2010 (Lemoigne et al., 2013) in the mangrove area.

In addition, the numerical approach can be further improved, particularly regarding the following:

- The resolution. Due to high computational costs, it was hardly possible to have a resolution better than $50 \mathrm{~m}$ at the coastline and for coral reefs. To get an idea of the po- 
tential error in water levels, we performed a few sensitivity tests with higher resolutions (typically $20-30 \mathrm{~m}$ ). The discrepancy was found to only amount to a few centimeters in shallow areas, where most of the stakes are exposed to storm surges. The coral reefs' geometry seems to be satisfactorily captured by the mesh, probably because the reefs are strongly eroded (so bathymetric gradients are relatively mild) and also because we ensured that the minimum water depths were correctly captured in these areas. However, a resolution of $50 \mathrm{~m}$ is probably insufficient to properly assess the wave setup component in areas where the slope is steep. For example, the results found are thus expected to be somewhat underestimated in the northwestern coast. Note, however, that these areas are generally not really exposed to storm surges. They are more prone to wave overtopping, which is not taken into account in this study and will require further work in the future.

- The phase-averaged model. Phase-averaged models suffer from several limitations. In particular, they do not deal with run-up, which might contribute significantly to shoreline inundation (e.g Ford et al., 2013). This can be the case for fringing coral reefs, for example, where the water level can be dominated by large lowfrequency (e.g., infragravity) waves. Indeed, during extreme events, the spectral wave energy at reef crests shifts into lower frequencies, which can be amplified due to resonance modes (e.g., Roberts et al., 1992; Péquinet et al., 2009; Cheriton et al., 2016). Even if (to our knowledge) large infragravity waves were not reported in Martinique, we see no reason to rule them out. In addition, climate change and sea level rise are expected to change the hydrodynamics across the reefs and might further increase the exposure of coastlines to these type of waves (e.g., Merrifield et al., 2014). This issue has been receiving more and more attention over the last years and will probably be a major topic of research in the near future.

- West-to-east tracks. A few hurricanes impacting Martinique and traveling eastward have been reported recently (e.g., Omar in 2008 or Lenny in 1999). Although several synthetic events with similar characteristics are included in our database, these events might be too infrequent to be properly represented from a statistical point of view. Since the hurricanes generally pass far away from Martinique, they are not expected to have large impacts on our computed 100-year surges in lowlying (surge prone) areas. However, larger errors can be expected for steep slopes on the western coast.

\section{Conclusions}

Using coupled wave-current numerical models and a dataset of synthetic hurricanes representing thousands of years of cyclonic activity in the central part of the Lesser Antilles, we presented a detailed analysis of storm surge hazard in Martinique for the present climate and started investigating the potential changes expected for the next decades. The 100year and extreme surge levels are found to be highest for the bay of Fort-de-France and the Atlantic coast (south of La Trinité, see Fig. 1 for location), where they can reach up to 4-5 and $3 \mathrm{~m}$ respectively. A very significant part of the surge (up to about $1 \mathrm{~m}$ on the eastern coast) can be due to the wave setup. The contribution of radiation stress gradients can even account for almost all the total surge in some special cases for example, for hurricanes making landfall in the northern part of Martinique that will induce essentially cross shore or offshore winds (and hence low wind setup) on the southeastern coast.

The nonlinear interactions of sea level rise with bathymetry and topography are generally found to be relatively small, with a reduction of surge by a few centimeters in many nearshore areas, because the wave setup is reduced and the wind is less efficient in driving water masses towards the shoreline with increasing water depths. However, they can amount to several tens of centimeters in specific low-lying areas (mangroves or lagoons for example) where the inundation extent is strongly enhanced compared to present conditions, due to SLR. These results provide further evidence that drawing inundation maps for the future without considering the nonlinear effects of sea level rise on water levels can lead to significant errors.

In the case of a large sea level rise in the coming decades, hurricanes striking Martinique could have devastating impacts in the bay of Fort-de-France, where most economical, historical and transportation stakes are located. According to some of our worst case scenarios, a large part of the Fort-deFrance urban area could be regularly flooded by hurricanes by the end of the 21st century. This finding also applies to the airport, located on the waterfront, and probably several major trunk roads.

The results presented in this paper can be further improved in terms of resolution, or by taking infragravity waves into account. The other impacts of climate change (evolution of coastal ecosystems and hurricane activity, for example) could also be investigated in greater detail. Some of those limitations are currently being addressed in the framework of $\mathrm{C} 3 \mathrm{AF}$, a project funded by the ERDF (European Regional Development Fund).

The methodology and results presented here should be of interest for other islands in the Lesser Antilles, as they display similar morphological features to Martinique, such as a relatively narrow shelf, contrasted slope morphologies, the presence of coral reefs and/or mangrove forests. This is confirmed, for instance, for the Guadeloupe archipelago, where 
very similar results in terms of 100-year surge levels (Krien et al., 2015), maximum water levels, or wave setup contribution are found.

Data availability. The 100-year surge data are freely available, provided that an agreement is signed with the University of the French West Indies. Please contact Professor Narcisse Zahibo (narcisse.zahibo@univ-ag.fr) for details.

Competing interests. The authors declare that they have no conflict of interest.

Acknowledgements. This work was supported by the INTERREG IV/TSUNAHOULE and FEDER/C3AF projects as well as by the Guadeloupe region. Many thanks to Kerry Emmanuel from the Massachusetts Institute of Technology for providing the synthetic storm datasets, as well as to Raphaël Pasquier, Jacques Laminie and Pascal Poullet (University of the French West Indies) for the setup of the computing cluster. We also express our gratitude to A. N. Lerma and another anonymous reviewer for their helpful comments and suggestions, which have led to a significantly improved manuscript.

Edited by: Thomas Glade

Reviewed by: Alexandre Nicolae Lerma and Michaela Spiske

\section{References}

Alongi, D. M.: Mangrove forests: resilience, protection from tsunamis, and response to global climate change, Estuar. Coast. Shelf S., 76, 1-13, 2008.

Baker, A. C., Glynn, P. W., and Riegl, B.: Climate change and coral reef bleaching: an ecological assessment of long-term impacts, recovery trends and future outlook, Estuar. Coast. Shelf S., 80, 435-471, 2008.

Barras, A. V., Oliveros, C., Joseph, B., and Marimoutou, C.: Inventaire et caractérisation des impacts de la houle sur le littoral de la Martinique au passage de l'ouragan Dean (17 août 2007), Rapport BRGM/RP-55954-FR, BRGM, France, 53 pp., 2008.

Battjes, J. A. and Janssen, J.: Energy loss and set-up due to breaking of random waves, in: 16th International Conference on Coastal Engineering, Coastal Engineering Research Council, Hamburg, Germany, 1978.

Bennis, A. C., Ardhuin, F., and Dumas, F.: On the coupling of wave and three dimensional circulation models: choice of theoretical framework, practical implementation and adiabatic tests, Ocean Model., 40, 260-272, 2011.

Booij, N., Ris, R. C., and Holthuijsen, L. H.: A third-generation wave model for coastal regions, Part I, model description and validation, J. Geophys. Res., 104, 7649-7666, 1999.

Bouchon, C. and Laborel, J.: Les peuplements coralliens des côtes de la Martinique, Annales de l'Institut Océanographique, Masson, 62, 199-238, 1986.

Brown, J. M., Bolaños, R., and Wolf, J.: Impact assessment of advanced coupling features in a tide-surge-wave model,
POLCOMS-WAM, in a shallow water application, J. Marine Syst., 87, 13-24, 2011.

Cavaleri, L. and Malanotte-Rizzoli, P.: Wind wave prediction in shallow water: theory and applications, J. Geophys. Res., 86, 10961-10973, 1981.

Cheriton, O. M., Storlazzi, C. D., and Rosenberger, K. J.: Observations of wave transformation over a fringing coral reef and the importance of low frequency waves and offshore water levels to runup, overwash, and coastal flooding, J. Geophys. Res.-Oceans, 121, 3121-3140, https://doi.org/10.1002/2015JC011231, 2016.

Condon, A. J. and Sheng, Y. P.: Evaluation of coastal inundation hazard for present and future climates, Nat. Hazards, 62, 345373, 2012.

Dehoorne, O., Tatar, C. F., and Augier, D.: The paradoxes of a tourism crisis: the example of the island of Martinique (French West Indies), Szczecin University Scientific Journal, No. 820, Service Management, 14, 69-85, 2014.

Desarthe, J.: Ouragans et submersions dans les Antilles françaises (XVIIème-Xxème siècle), Etudes caribéennes, 29, 7176, https://doi.org/10.4000/etudescaribeennes.7176, 2014.

Dietrich, J. C., Zijlema, M., Westerink, J. J., Holthuijsen, L. H., Dawson, C., Luettich, R. A., Jensen, R. E., Smith, J. M., Stelling, G. S., and Stone, G. W.: Modeling hurricane waves and storm surge using integrally-coupled scalable computations, Coast. Eng., 58, 45-65, 2011 a.

Dietrich, J. C., Westerink, J. J., Kennedy, A. B., Smith, J. M., Jensen, R. E., Zijlema, M., Holthuijsen, L. H., Dawson, C. N., Luettich Jr., R. A., Powell, M. D., Cardone, V. J., Cox, A. T., Stone, G. W., Pourtaheri, H., Hope, M. E., Tanaka, S., Westerink, L. G., Westerink, H. J., and Cobell, Z.: Hurricane Gustav (2008) waves and storm surge: hindcast, synoptic analysis, and validation in Southern Louisiana, Mon. Weather Rev., 139, 2488-2522, 2011b.

Dietrich, J. C., Tanaka, S., Westerink, J. J., Dawson, C. N., Luettich Jr., R. A., Zijlema, M., Holthuijsen, L. H., Smith, J. M., Westerink, L. G., and Westerink, H. J.: Performance of the unstructured-mesh, SWAN + ADCIRC model in computing hurricane waves and surge, J. Sci. Comput., 52, 468-497, 2012.

Durand, F., Vernette, G., and Augris, C.: Cyclonic risk in Martinique and response to hurricane Allen, J. Coastal Res., 24, 17 27, 1997.

Dutour Sikiric, M., Roland, A., Janekovic, I., Tomazic, I., and Kuzmic, M.: Coupling of the regional ocean modelling system and wind wave model, Ocean Model., 72, 59-73, 2013.

Duvat, V.: Changement climatique et risques côtiers dans les îles tropicales, Annales de Géographie, 705, 541-566, 2015.

Eldeberky, Y.: Nonlinear transformations of wave spectra in the Nearshore Zone, PhD thesis, Delft University of Technology, Delft, the Netherlands, p. 203, 1996.

Emanuel, K. and Rotunno, R.: Self-stratification of tropical cyclone outflow, Part I: Implications for storm structure, J. Atmos. Sci., 68, 2236-2249, 2011.

Emanuel, K., DesAutels, C., Holloway, C., and Korty, R.: Environmental control of tropical cyclone intensity, J. Atmos. Sci., 61, 843-858, 2004.

Emanuel, K., Ravela, S., Vivant, E., and Risi, C.: A statistical deterministic approach to hurricane risk assessment, B. Am. Meteorol. Soc., 87, 299-314, 2006 
EPRI: L'évaluation préliminaire des risques d'inondation 2011Bassin Martinique, Rapport, DEAL, Martinique, France, 2012.

European Union: SoeS CORINE Land Cover, EU, MTES, Paris, France, 2006.

Ferrario, F., Beck, M. W., Storlazzi, C. D., Micheli, F., Shepard, C. C., and Airoldi, L.: The effectiveness of coral reefs for coastal hazard risk reduction and adaptation, Nat. Commun., 5, 3794, https://doi.org/10.1038/ncomms4794, 2014.

Ford, M. R., Becker, J. M., and Merrifield, M. A.: Wave processes and excavation pits: observations and implications for Majuro Atoll, Marshall Islands, J. Coastal Res., 29, 545-554, 2013.

Garnier, E., Desarthe, J., and Moncoulon, D.: The historic reality of the cyclonic variability in French Antilles, 1635-2007, Clim. Past Discuss., 11, 1519-1550, https://doi.org/10.5194/cpd11-1519-2015, 2015.

Gilman, E. L., Ellison, J., Duke, N. C., and Field, C.: "Threats to mangroves from climate change and adaptation options: a review", Aquat. Bot., 89, 237-250, 2008.

Grau, A. and Roudil, L.: Réalisation de prestations nécessaires à l'élaboration de cartes de surfaces inondables sur les Territoires à Risques Importants d'inondations (TRI), Rapport d'accompagnement, Egis Eau, Martinique, France, 2013.

Haigh, I. D., MacPherson, L. R., Mason, M. S., Wijeratne, E. M. S., Pattiaratchi, C. B., Crompton, R. P., and George, S.: Estimating present day extreme water level exceedance probabilities around the coastline of Australia: tropical cyclone-induced storm surges, Clim. Dynam., 42, 139-157, 2014.

Harper, B., Hardy, T., Mason, L., and Fryar, R.: Developments in storm tide modelling and risk assessment in the Australian region, Nat. Hazards, 51, 225-238, 2009.

Hasselmann, S., Hasselmann, K., Allender, J. H., and Barnett, T. P.: Computations and parameterizations of the linear energy transfer in a gravity wave spectrum, II, parameterizations of the nonlinear transfer for application in wave models, J. Phys. Oceanogr., 15, 1378-1391, 1985.

Hoegh-Guldberg, O., Mumby, P. J., Hooten, A. J., Steneck, R. S., Greenfield, P., Gomez, E., Harvell, C. D., Sale, P. F., Edwards, A. J., Caldeira, K., Knowlton, N., Eakin, C. M., Iglesias Prieto, R., Muthiga, N., Bradbury, R. H., Dubi, A., and Hatziolos, M. E.: Coral reefs under rapid climate change and ocean acidification, Science, 318, 1737-1742, 2007.

Holland, G. J.: An analytic model of the wind and pressure profiles in hurricanes, Mon. Weather Rev., 108, 1212-1218, 1980.

Hope, M. E., Westerink, J. J., Kennedy, A. B., Kerr, P. C., Dietrich, J. C., Dawson, C., Bender, C.,Smith, J. M., Jensen, R. E., Zijlema, M., Holthuijsen, L. H., Luettich, R. A., Powell, M. D., Cardone, V. J., Cox, A. T., Pourtahen, H., Roberts, H. J., Atkinson, J. H., Tanaka, S., Westerink, H. J., and Westerink, L. G.: Hindcast and validation of hurricane Ike (2008): waves, forerunner, and stormsurge, J. Geophys. Res.-Oceans, 118, 4424-4460, 2013.

IFRECOR: Etat des récifs coralliens et des écosystèmes associés des Outre-mer français en, 2015, DEAL, La Réunion, France, 168 pp., 2016.

Imbert, D. and Migeot, J.: Impact de l'Ouragan Dean sur les forêts côtières inondables de la Martinique: le cas de la mangrove de Ducos et de la forêt marécageuse du Galion, DEAL, Martinique, France, Rapport pour DIREN, 16 pp., 2009.
IPCC: Summary for policymakers, in: Climate Change 2013: The Physical Science Basis, Contribution of Working Group I to the Fifth Assessment Report of the Intergovernmental Panel on Climate Change, edited by: Stocker, T. F., Qin, D., Plattner, G.K., Tignor, M., Allen, S. K., Boschung, J., Nauels, A., Xia, Y., Bex, V. and Midgley, P. M., Cambridge University Press, Cambridge, UK and New York, NY, USA, 33 pp., 2013.

Kennedy, A. B., Gravois, U., Zachry, B. C., Westerink, J. J., Hope, M. E., Dietrich, J. C., Powell, M. D., Cox, A. T., Luettich Jr., R. A., and Dean, R. G.: Origin of the hurricane Ike forerunner surge, Geophys. Res. Lett., 38, L08608, https://doi.org/10.1029/2011GL047090, 2011.

Knutson, T., McBride, J., Chanm, J., Emanuel, K., Holland, G., Landsea, C., Held, I., Kossin, J., Srivastava, A., and Sugi, M.: Tropical cyclones and climate change, Nat. Geosci., 3, 157-163, 2010.

Komen, G. J., Hasselmann, S., and Hasselmann, K.: On the existence of a fully developed wind-sea spectrum, J. Phys. Oceanogr., 14, 1271-1285, 1984.

Krien, Y.: Note technique projet TSUNAHOULE: évaluation des périodes de retour des surcotes cycloniques dans les Antilles Françaises, Report, Université des Antilles, Guadeloupe, France 2013.

Krien, Y., Dudon, B., Roger, J., and Zahibo, N.: Probabilistic hurricane-induced storm surge hazard assessment in Guadeloupe, Lesser Antilles, Nat. Hazards Earth Syst. Sci., 15, 17111720, https://doi.org/10.5194/nhess-15-1711-2015, 2015.

Kumar, N., Voulgaris, G., Warner, J. C., and Olabarrieta, M.: Implementation of the vortex force formalism in the coupled oceanatmosphere-wave-sediment transport (COAWST) modelling system for inner shelf and surf zone applications, Ocean Model., 47, 65-95, 2012.

Legrand, H., Rousseau, Y., Peres, C., and Marechal, J. P.: Suivi écologique des récifs coralliens des stations IFRECOR en Martinique de 2001 à 2006, Revue d'Ecologie (Terre Vie), 63, 67-84, 2008.

Lemoigne, B., Paulineau, M., Nachbaur, A., and Stépanian A.: Établissement d'un état de référence du trait de côte de la Martinique: situation en 2010 et évolution historique depuis 1951, BRGM, Martinique, France, Rapport final, BRGM/RP-61686FR150, 85 pp., 2013.

Léone, F.: Caractérisation des vulnérabilités aux catastrophes naturelles: contribution à une évaluation géographique multirisque, Habilitation à diriger des recherches, Université Paul Valéry, Montpellier III, Montpellier, 2007.

Levitus, S. E.: Climatological atlas of the world ocean, NOAA Professional Paper 13, US Government Printing Office, Washington DC, 1982.

Lin, N., Emanuel, K. A., Smith, J. A., and Vanmarcke, E.: Risk assessment of hurricane storm surge for New York City, J. Geophys. Res.-Atmos., 115, D18121, https://doi.org/10.1029/2009JD013630, 2010.

Lin, N., Emanuel, K., Oppenheimer, M., and Vanmarcke, E.: Physically based assessment of hurricane surge threat under climate change, Nat. Clim. Change, 2, 462-467, 2012.

Luettich, R. A., Westerink, J. J., and Scheffner, N. W.: ADCIRC: an advanced three-dimensional circulation model for shelves, coasts and estuaries, Report 1: theory and methodology of ADCIRC2DDI and ADCIRC-3D L, U.S. Army Engineers Waterways Ex- 
periment Station, Vicksburg, MS, Technical Report DRP-92-6, 137 pp., 1992.

Madsen, O. S., Poon, Y.-K., and Graber, H. C.: Spectral wave attenuation by bottom friction: theory, in: Proceedings of the 21st International Conference on Coastal Engineering, Reston, 492504, 1988.

Merrifield, M. A., Becker, J. M., Ford, M., and Yao, Y.: Observations and estimates of wave-driven water level extremes at the Marshall Islands, Geophys. Res. Lett., 41, 7245-7253, https://doi.org/10.1002/2014GL061005, 2014.

Meteo France: Evaluation du risque lié aux surcotes cycloniques sur les Antilles Françaises, Meteo France, France, Report, 2002.

Murty, P. L. N., Bhaskaran, P. K., Gayathri, R., Sahoo, B., Srinivasa Kumar, T., and SubbaReddy, B.: Numerical study of coastal hydrodynamics using a coupled model for Hudhud cyclone in the Bay of Bengal, Estuar. Coast. Shelf S., 183, 13-27, https://doi.org/10.1016/j.ecss.2016.10.013, 2016.

Neumann, B., Vafeidis, A. T., Zimmermann, J., and Nicholls, R. J.: Future coastal population growth and exposure to sea-rise and coastal flooding - a global assessment, Plos One, 10, e0118571 https://doi.org/10.1371/journal.pone.0118571, 2015.

Nicolae Lerma, A., François, T. Y., Saffache, P., Durand, P., and Lamy, M.: Modélisation des niveaux marins extrêmes associés à la circulation des cyclones Lenny (1999): et Omar (2008), commune de saint-pierre, littoral nord-ouest de la Martinique, Vertigo, 14, 24 pp., https://doi.org/10.4000/vertigo.15326, 2014.

Niedoroda, A. W., Resio, D. T., Toro, G. R., Divoky, D., Das, H. S., and Reed, C. W: Analysis of the coastal Mississippi storm surge hazard, Ocean Eng., 37, 82-90, 2010.

Pagney, F. and Léone, F.: Les Antilles, terres à risques, Karthala, Paris, 1999.

Palanisamy, H., Becker, M., Meyssignac, B., Henry, O., and Cazenave, A.: Regional sea level change and variability in the Caribbean Sea since 1950, Journal of Geodetic Science, 2, 2125133, 2012.

Pequignet, A.-C., Becker, J. M., Merrifield, M. A., and Aucan, J.: Forcing of resonant modes on a fringing reef during tropical storm Man-Yi, Geophys. Res. Lett., 36, L03607, https://doi.org/10.1029/2008GL036259, 2009.

PGRI: Plan de Gestion des Risques d'Inondation de Martinique (PGRI), Rapport DEAL Martinique, Egis Eau, Martinique, France, 2014.

Poisson, B. and Pedreros, R.: Tsunamis: étude de cas au niveau de la côte antillaise française - Modélisation numérique, BRGM, Orléans, Rapport BRGM/RP 55761, 111 pp., 2007.

Qi, J., Chen, C., Beardsley, R. C., Perrie, W., Cowles, G. W., and Lai, Z.: An unstructured-grid finite-volume surface wave model (FVCOM-SWAVE): implementation, validations and applications, Ocean Model., 28, 153-166, 2009.

Resio, D. T.: White Paper on Estimating Hurricane Inundation Probabilities, US Army Corps of Engineers, Engineer Research and Development Center, Vicksburg, MS, 2007.

Roberts, H. H., Wilson, P. A., and Lugo-Fernandez, A.: Biologic and geologic responses to physical processes: examples from modern reef systems of the Caribbean-Atlantic region, Cont. Shelf Res., 12, 809-834, 1992.

Roland, A., Zhang, Y. J., Wang, H. V., Meng, Y., Teng, Y. C., Maderich, V., Brovchenko, I., Dutour-Sikiric, M., and Zanke, U.: A fully coupled 3-D wave-current interaction model on unstructured grids, J. Geophys. Res., 117, C00J33, https://doi.org/10.1029/2012JC007952, 2012.

Rousseau, Y., Galzin, R., and Marechal, J. P.: Impact of hurricane Dean on coral reef benthic and fish structure of Martinique, French West Indies, Cybium, 34, 243-256, 2010.

Saffache, P.: Le littoral martiniquais: milieux, dynamiques et gestion des risques, Villeneuve d'Ascq: Presses Universitaires du Septentrion, France, 2000.

Saffache, P., Marc, J. V., Cospar, O.: Les cyclones en Martinique: quatre siècles cataclysmiques (éléments pour une prise de conscience de la vulnérabilité de l'île de la Martinique), Paris: Ibis Rouge Éditions, Collection Géographie and Aménagement des Espaces Insulaires, Presses Universitaires Créoles, Paris, France, 197 pp., 2002.

Sansorgne, E.: Etude de la méthode des fonctions réponses pour la prévision des surcotes cycloniques dans les Antilles: exemple de la baie du Robert, Martinique, Rapport Master 2, Université des Antilles, Guadeloupe, France, 2013.

Thabard, M. and Pouget-Cuvelier, A.: Incidences des échouages de sargasses pélagiques sur les côtes Martiniquaises, Présentation IFRECOR, Martinique, France, 2014.

Toro, G. R., Niedoroda, A. W., Reed, C., and Divoky, D.: Quadrature-based approach for the efficient evaluation of surge hazard, Ocean Eng., 37, 114-124, 2010.

Waycott, M., Duarte, C. M., Carruthers, T. J. B., Orth, R. J., Dennison, W. C., Olyarnik, S., Calladine, A., Fourqurean, J. W., Heck, K. L., Hughes, A. R., Kendrick, G. A., Kenworthy, W. J., Short, F. T., and Williams, S. L.: Accelerating loss of seagrasses across the globe threatens coastal ecosystems, P. Natl. Acad. Sci. USA, 106, 12377-12381, 2009

Westerink, J. J., Luettich, R. A., Blain, C. A., and Scheffner, N. W.: ADCIRC: an advanced three-dimensional circulation model for shelves, coasts and estuaries, Report 2: users' manual for ADCIRC-2DD I, Technical report DRP-94, US Army Corps of Engineers, Vicksburg, MS, USA, 1994a.

WMO: Atlas of Mortality and Economic Losses From Weather, in: Climate and Water Extremes (1970-2012), World Meteorological Organization, Geneva, 1123, 2014.

Wolf, J., Brown, J. M., Bolaños, R., and Hedges, T.: Waves in coastal and estuarine waters, in: Treatise on Estuarine and Coastal Science, 2, edited by: Wolanski, E., and McLusky, D., Elsevier, USA, 171-212, 2011.

Wong, P. P., Losada, I. J., Gattuso, J.-P., Hinkel, J., Khattabi, A., K. L. McInnes, Saito, Y., and Sallenger, A.: Coastal systems and low-lying areas, in: Climate Change 2014: Impacts, Adaptation, and Vulnerability, Part A: Global and Sectoral Aspects, Contribution of Working Group II to the Fifth Assessment Report of the Intergovernmental Panel on Climate Change, edited by: Field, C. B., Barros, V. R., Dokken, D. J., Mach, K. J., Mastrandrea, M. D., Bilir, T. E., Chatterjee, M., Ebi, K. L., Estrada, Y. O., Genova, R. C., Girma, B., Kissel, E. S., Levy, A. N., MacCracken, S., Mastrandrea, P. R., and White, L. L., Cambridge University Press, Cambridge, UK and New York, NY, USA, 361-409, 2014.

Zijlema, M.: Computation of wind-wave spectra in coastal waters with SWAN on unstructured grids, Coast. Eng., 57, 267-277, 2010. 